\title{
Impact of water stress on various plant traits of different tomato varieties at early growth stage
}

Shahzadi Mahpara ${ }^{1 *}$, Irsa Andleeb ${ }^{1}$, Muhammad Amjad Bashir ${ }^{2}$, Javaid Iqbal $^{3}$ and Ijaz Rasool Noorka ${ }^{4}$

1. Department of Plant Breeding \& Genetics, Faculty of Agricultural Sciences, Ghazi University, D.G. KhanPakistan

2. Department of Plant Protection, Faculty of Agricultural Sciences, Ghazi University, D.G. Khan-Pakistan

3. Department of Agronomy, Faculty of Agricultural Sciences, Ghazi University, D.G. Khan-Pakistan

4. Department of Plant Breeding \& Genetics, University College of Agriculture, University of Sargodha-Pakistan

*Corresponding author's email: mahpara.gudgk@gmail.com

Citation

Shahzadi Mahpara, Irsa Andleeb, Muhammad Amjad Bashir, Javaid Iqbal and Ijaz Rasool Noorka. Impact of water stress on various plant traits of different tomato varieties at early growth stage. Pure and Applied Biology. Vol. 7, Issue 3, pp1038-1051. http://dx.doi.org/10.19045/bspab.2018.700123

\begin{tabular}{llll}
\hline \hline Received: 04/06/2018 & Revised: 01/08/2018 & Accepted: 02/08/2018 & Online First: 03/08/2018 \\
\hline \hline
\end{tabular}

\section{Abstract}

Tomato belongs to family solanaceae and is a source of many antioxidants important for human health like B- carotene, lycopene, ascorbic acid etc. Its production is challenged by many abiotic stresses including water stress on the top. Genetic potential of ten tomato genotypes was evaluated under normal and water stress conditions in Department of Plant Breeding \& Genetics, Ghazi University, D. G. Khan. Nursery of these genotypes was raised in plastic pots. Seedlings were transplanted in the field under completely randomized block design (RCBD) after three to four weeks of germination. Data on various seedling traits were recorded. Highly significant results were found for analysis of variance in many plant traits. Correlation analysis indicated vegetative traits have mostly positive and significant association with each other like plant height and number of leaves have positive correlation with number of branches. GIACIER and DONA among all genotypes of tomato having best performance under normal and water stress conditions for plant traits like root length, fresh shoot weight, fresh root weigh, dry root weight, number of branches and plant height. So, these varieties are recommended for further breeding program and can be grown under water stress conditions for high yield.

Keywords: Correlation; Genetic variability; Plant traits; Tomato; Vegetative stage

\section{Introduction}

Tomato is an important agriculture commodity. It is most popular and widely consume among vegetables in world. Tomato fruit is perishable commodity with shorter shelf-life under normal temperature. They are rich in minerals and vitamins especially vitamin $\mathrm{A}, \mathrm{B}$ and $\mathrm{C}$ and also contain iron and phosphorus. More than $80 \%$ tomato is used in processed products like tomato juice, paste, pure ketchup, sauce and salsa. Due to presence of lycopene content tomato produce deep red color in fruits and products [1].

During recent decades, the utilization of tomatoes has been associated with prevention of several diseases due to the presences of 
antioxidants contents including $\beta$-carotene as well as lycopene, ascorbic acid, and some phenolic compounds. [2]

In Pakistan tomatoes are cultivated in both rabi and kharif seasons. Area of tomato production increased from 57215 hec to 58196 hec during 2012-2013, its production lowered from 577803 tonnes to 574052 tonnes, whereas export grew up from 7095490 to 15765528 tonnes and import dropped from 270817 tonnes to 214891 tonnes during same year [3]. Out of total cultivated land area of Pakistan, Punjab has area of 20.6 mhec, out of which 11.04 mhec is cultivated and $5 \mathrm{mhec}$ of total cultivated land area of country is rain fed.

Water stress (drought) affect the morphological characters of plants like reduced plant height, number of leaves, leaf size, stem diameter, poor quality of fruits and seeds. It has adverse impact on physiological changes which cause reduction in photosynthesis, respiration, transpiration and cell division. Lower production of protein, carbohydrates and enzymes observed at biochemical level. As a result overall production of a crop is decreased. Healthy and resistant seedlings provide protection against different stresses either abiotic or biotic resulting high yield. Survival of seedling particularly, has been considered as one of the major blockage processes for plant regeneration in several Mediterranean plants type [4].

Tomato crop is cultivated in whole world but mostly growing areas are arid and semi-arid where salinity is a major problem [5]. Commercial tomato cultivars are drought sensitive. But crop physiology and genomics have led to stages of plant development, with seed germination and new insights in drought tolerance provide breeders with early seedling growth being the most sensitive stages. Water stress is the major abiotic stress that limits crop productivity worldwide [6]. Water stress also modified the level of organic osmolytes like Glycine betaine (GB) and proline in plants [7] and it was observed that effect of exogenous glycine betaine had an impact on morpho-physiological characteristics of tomato and it was revealed that vegetative growth parameters, root length, leaf number, leaf area and physiological characteristics, i.e. shoot fresh weight, total shoot dry weight, relative water content and stress tolerance index were decreased with the increase of water stress. Similarly, shortage of water causes reduction in shoot length and biomass of tomato plant at both vegetative and reproductive growth stages $[8,9]$.

Foremost focus of this study was to estimate genetic variability in available tomato germplasm for growth related traits and to find out best performer genotype under stress condition. A stringent screening of the starting material is crucial for breeding success. The fact that there is no universal selection criterion for differentiating tolerant and sensitive accessions raises the need for investigating the effects of water shortage on various tomato traits $[10,11]$. These findings will help tomato breeders to develop tomato varieties through hybridization with improved drought tolerance in tomato breeding program.

\section{Materials and methods}

The experiment was conducted at an experimental area of Department of Plant Breeding \& Genetics, Ghazi University, Dera Ghazi Khan under normal and water stress conditions. Sandy loam soil mixed with farm yard manure was used as growing media with $2: 1 \%$ ratio. Ten tomato cultivars i.e. PRESCOTT, SASHA, LA-3847, SUBARCTIC, GIACIER, CANILES, AVOT-1008, AVOT-1007, DONA and ROOMA-F1 were sown in seedling small plastic pots. Three-weeks-old seedlings of 
each genotype were transplanted in the field following RCBD. In each cultivar, 10 plants were transplanted in each row for each genotype. Two treatments i.e. normal and drought were applied on plants replicated thrice. In case of normal treatment, irrigation was applied according to field capacity level and drought was created when water was applied half of the normal supply. All standard cultural and plant protection measures were followed till harvest of the crop. When plants became 8-weeks-old, five plants per genotype in each replication were selected randomly for both treatments for plant height, number of leaves per plants, number of branches per plant, root length, fresh shoot weight, dry shoot weight, fresh root weight, and dry root weight for analysis of data.

Effects of applied treatments on different parameters were analyzed using analysis of various (ANOVA) technique [12]. Plant traits which showed significance, their genotypic and phenotypic correlation was also estimated according to statistical techniques outline by Kown and Torrie [13].

\section{Results}

\section{Genetic variability}

The results (Table 1) indicated that there was significant difference in performance of plants under both treatments for plant traits like, number of leaves per plant, number of branches per plant, root length, fresh shoot weight, fresh root weight, dry shoot weight, dry root weight. Genotypic differences were also found significant in all studied plant traits and interaction between treatment and genotypes was also significant which indicated significant relationship between both treatments $\left(\mathrm{T}_{1}\right.$ and $\left.\mathrm{T}_{2}\right)$ has different effect on each variety under study.

\section{Comparison of mean squares}

Table 2 depicted the maximum number of leaves per plant was found in variety 5 GIACIER (74.17). Figure 1 represented that more number of leaves per plant under irrigation conditions than under drought.

LSD test among varieties V5 GAICIER (13.84) and V10 ROOMA- F1 (13.5) were persistent in producing significant results regarding number of branches per plant both under normal and drought conditions. Variety 5 produced maximum number of branches per plant both under normal conditions and drought conditions while variety 7 AVOT-1007 (11.17) produced minimum number of branches both under normal and drought conditions. Figure 2 indicated that number of branches per plant increased under irrigation conditions than that of drought.

Maximum shoot length was attained by varieties V5 and V9 according to (Table 2). Similarly as depicted in (Figure 3), shoot length was significantly reduced due to effect of water stress as compared to the plants that were grown under normal conditions of irrigation.

For root length, varieties V3 GASICER (14.27) and V9 DONA (14.24) were persistent in producing amplified roots as comparative to rest of varieties. Varieties V5 and V9 produced significantly prolonged roots while V4, V6 and V10 produced least roots. Significantly reduction in root length for all varieties under drought conditions was found as compared to varieties under normal conditions (Figure 4).

Similarly, V9 DONA (361.87) was producing maximum fresh shoot weight and variety V8 AVOOT-7 (336.08) produced minimum shoot fresh weight. Figure 5 indicated that shoot fresh weight was increased under normal irrigation conditions than under drought conditions. For plant trait shoot dry biomass, Varieties V4 and V5 also produced considerable best and were similar with other varieties which produced maximum shoot dry biomass i.e, V9 and V10. There was no significant difference among rest of the six varieties regarding 
shoot dry weight. There was significant reduction in shoot dry weight in all varieties under drought conditions as compared to normal conditions of water supply (Figure 6). Varieties V1 and V9 produced maximum dried weight of roots. There was significant reduction in root dry weight in all varieties under drought conditions as compared to normal conditions of water supply with exception of varieties V4, V5 and V6. Figure 7 depicted that root dry weight increased under normal irrigation conditions than drought for comparison of both treatments.

Among varieties, V5 GAISER and V8 produced maximum root fresh weight and significant as compared to all other varieties (Table 2). While V2 SHSHA produced minimum root fresh biomass. Figure 8 found increased in this traits under normal conditions than under drought conditions.

\section{Correlations analysis}

In order to further investigate the effects of normal irrigation and water stress on various traits of different varieties, phenotypic and genotypic correlation was carried out and their significance was tested (Table 3). A positive and very strong genotypic and phenotypic significant correlation $(\mathrm{rG}=0.96$ and $\mathrm{rP}=0.32$ ) was found between number of leaves per plant and root length $(\mathrm{rp}=0.71$ and $\mathrm{rG}=0.30$ ) there was significant but negative genotypic correlation between leaves /plant and number of branches per plant (-0.99). Similarly, strong genotypic and phenotypic correlation $(\mathrm{rG}=0.81$ and $\mathrm{rP}=0.41)$ was observed between number of leaves per plant and root fresh weigh was observed. A positive and very strong genotypic and phenotypic correlation $(\mathrm{rG}=0.80$ and $\mathrm{rP}=$ 0.30) was found between number of leaves per plant and shoot fresh under water stress conditions. Number of leaves per plant was found phonotypical significantly correlated with root length $(\mathrm{rp}=0.30)$, number of branches per plant $(\mathrm{rp}=0.39)$, root fresh weight $(\mathrm{rp}=0.30)$ and root dry weight $(\mathrm{rp}=$ $0.32)$ all other traits shoot fresh weight $(\mathrm{rG}=$ $0.80)$, root dry weight $(\mathrm{rG}=0.63)$, root fresh weight $(\mathrm{rG}=0.52)$ were also found genetically significantly correlated. Significant and positive genotypic correlation was found between these traits number of leaves per plant and plant height ( $\mathrm{rG}=0.34)$, shoot dry weight with number of leaves per plant $(\mathrm{rG}=0.33)$.

Similarly, strong genotypic and phenotypic correlation $(\mathrm{rG}=0.99$ and $\mathrm{rP}=0.52$ ) was observed between plant height and shoot dry weight and with shoot fresh weight $(\mathrm{rG}=0.81$ and $\mathrm{rP}=0.33$ ) which is evident from the table. The traits that possessed only phenotypic correlation with plant height were root dry weight and root fresh weight with phenotypic significant correlation co-efficient $\mathrm{rP}=0.38$ and $\mathrm{rP}=0.36$, respectively they there was positive genotypic significant correlation between plant height and root length $(\mathrm{rG}=0.16)$, root dry weight $(\mathrm{rG}=0.57)$, root fresh weight $(\mathrm{rG}=0.53)$.

Root length under water stress conditions was genetically showed strong positive correlation $(\mathrm{rG}=0.99)$ as well as phenotypic significant positive correlation $(\mathrm{rP}=0.58)$ root fresh weight indicating that the varieties that have gene heritability to tolerate drought conditions will produce long and consequently more root fresh biomass to explore more water from water deficit soil. Shoot dry weight was also found to have strong positive genetic correlation with root fresh weight $(\mathrm{rG}=0.91)$ and also possessed strong phenotypic correlation $(\mathrm{rP}=0.53)$. 
Table 1. Analysis of variance among various plant traits in different tomato genotypes at early growth stage

\begin{tabular}{|c|c|c|c|c|c|c|c|c|c|}
\hline Source & DF & $\begin{array}{c}\text { Number of } \\
\text { Leaves per } \\
\text { Plant }\end{array}$ & Shoot length & $\begin{array}{c}\text { Number of } \\
\text { branches per } \\
\text { plant }\end{array}$ & Root length & Fresh shoot wt. & Dry shoot wt. & Fresh root wt. & Dry root wt. \\
\hline Replications & 2 & 0.82 & 1.042 & 0.317 & 1.045 & 140.2 & 14.88 & 5.365 & 0.313 \\
\hline Treatments & 1 & $559.98^{*}$ & $166.85^{*}$ & $159.13^{*}$ & $235.15^{*}$ & $1050.04 *$ & $536.81 *$ & $152.83^{*}$ & $146.67 *$ \\
\hline Varieties & 9 & $5.65^{*}$ & $9.87 *$ & $2.04 *$ & $2.42 *$ & $6.93 *$ & $7.14 *$ & $5.89 *$ & $17.53^{*}$ \\
\hline $\begin{array}{c}\text { Treatment } \times \\
\text { varieties }\end{array}$ & 9 & $0.41 *$ & $1.96^{*}$ & $0.23 *$ & $2.21 *$ & $2.04 *$ & $2.38 *$ & $0.89 *$ & $0.98 *$ \\
\hline Error & 38 & & & & & & & & \\
\hline
\end{tabular}

**, Significant at $\mathrm{P} \leq 0.01$; Significant at $\mathrm{P} \leq 0.05$; NS, Non-significant at $\mathrm{P}>0.05$

Table 2. Least Significant Differences (LSD) test for seedling plant traits in different tomato genotypes at early growth stage

\begin{tabular}{|c|c|c|c|c|c|c|c|c|c|}
\hline Genotype & $\begin{array}{l}\text { Names of } \\
\text { Genotype }\end{array}$ & $\begin{array}{c}\text { Number of } \\
\text { leaves per } \\
\text { plant }\end{array}$ & $\begin{array}{l}\text { Shoot } \\
\text { length }\end{array}$ & $\begin{array}{c}\text { Root } \\
\text { length }\end{array}$ & $\begin{array}{c}\text { Number of } \\
\text { branches per plant }\end{array}$ & $\begin{array}{l}\text { Dry shoot } \\
\text { weight }\end{array}$ & $\begin{array}{l}\text { Fresh Shoot } \\
\text { weight }\end{array}$ & $\begin{array}{l}\text { Root dry } \\
\text { weight }\end{array}$ & Fresh root weight \\
\hline V5 & GIACIER & $74.17 \mathrm{a}$ & $41.4 \mathrm{a}$ & $14.24 \mathrm{a}$ & $13.84 \mathrm{a}$ & $112.04 \mathrm{ab}$ & $60.64 \mathrm{a}$ & $20.77 \mathrm{a}$ & $350.24 \mathrm{bc}$ \\
\hline $\mathrm{V} 10$ & ROOMA-F1 & $73.17 \mathrm{ab}$ & $36.4 \mathrm{~cd}$ & $11.49 \mathrm{c}$ & $13.5 \mathrm{ab}$ & $113.77 \quad \mathrm{a}$ & $54.64 \mathrm{~cd}$ & $17.18 \mathrm{~b}$ & $355.54 \mathrm{ab}$ \\
\hline V9 & DONA & $71.34 \mathrm{abc}$ & $40.4 \mathrm{ab}$ & $14.25 \mathrm{a}$ & $12.67 \mathrm{abc}$ & $114.35 \quad \mathrm{a}$ & $58.62 \mathrm{ab}$ & $20.88 \mathrm{a}$ & $361.87 \mathrm{a}$ \\
\hline V 8 & AVOT-1007 & $72 \mathrm{ab}$ & $34.74 \mathrm{~d}$ & $13.19 \mathrm{a}$ & $12.34 \mathrm{abc}$ & $105.87 \mathrm{~cd}$ & $57.1 \mathrm{bc}$ & $16.96 \mathrm{~b}$ & $337.25 \mathrm{~d}$ \\
\hline $\mathrm{V} 4$ & SUBARATIC & 67.17 cde & $39.77 \mathrm{ab}$ & $11.62 \mathrm{c}$ & $12.34 \mathrm{abc}$ & $113.72 \mathrm{a}$ & $57.28 \mathrm{bc}$ & $17.08 \mathrm{~b}$ & $341.39 \mathrm{~cd}$ \\
\hline $\mathrm{V} 1$ & PRESCOT & $73.34 \mathrm{ab}$ & $40.28 \mathrm{ab}$ & $13 \mathrm{ab}$ & $12.34 \mathrm{abc}$ & $105.55 \mathrm{~d}$ & $57.25 \mathrm{bc}$ & $17.07 \mathrm{~b}$ & 350.94 bc \\
\hline V 3 & LA-3847 & $72 \mathrm{ab}$ & $38.12 \mathrm{bc}$ & $14.27 \mathrm{a}$ & $12.34 \mathrm{abc}$ & $109.72 \mathrm{bc}$ & $58.27 \mathrm{ab}$ & $19.74 \mathrm{a}$ & $342.09 \mathrm{~cd}$ \\
\hline $\mathrm{V} 2$ & SHSHA & $64 \mathrm{e}$ & $38.32 \mathrm{bc}$ & $11.85 \mathrm{bc}$ & $11.8 \mathrm{bc}$ & $108.85 \mathrm{bcd}$ & $52.64 \mathrm{~d}$ & $17.2 \mathrm{~b}$ & $352.94 \quad \mathrm{ab}$ \\
\hline V 6 & CANLIES & $69 \mathrm{bcd}$ & $35.54 \mathrm{~d}$ & $11.67 \mathrm{c}$ & $11.5 \mathrm{c}$ & $107.27 \mathrm{~cd}$ & $54.9 \mathrm{~cd}$ & $17.05 \mathrm{~b}$ & $340.59 \mathrm{~cd}$ \\
\hline V7 & AVOT-1007 & $65.5 \mathrm{de}$ & $35.08 \mathrm{~d}$ & $13.3 \mathrm{a}$ & $11.17 \mathrm{c}$ & $107.65 \mathrm{~cd}$ & $58.18 \mathrm{ab}$ & $17.44 \mathrm{~b}$ & $336.08 \mathrm{~d}$ \\
\hline
\end{tabular}




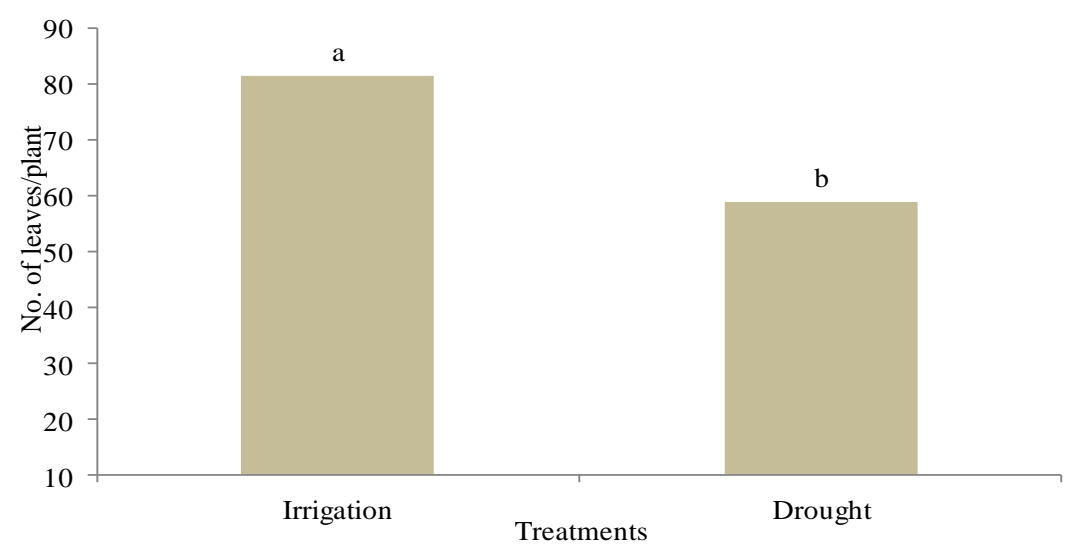

Figure 1. Main effect of treatment on number of leaves per plant

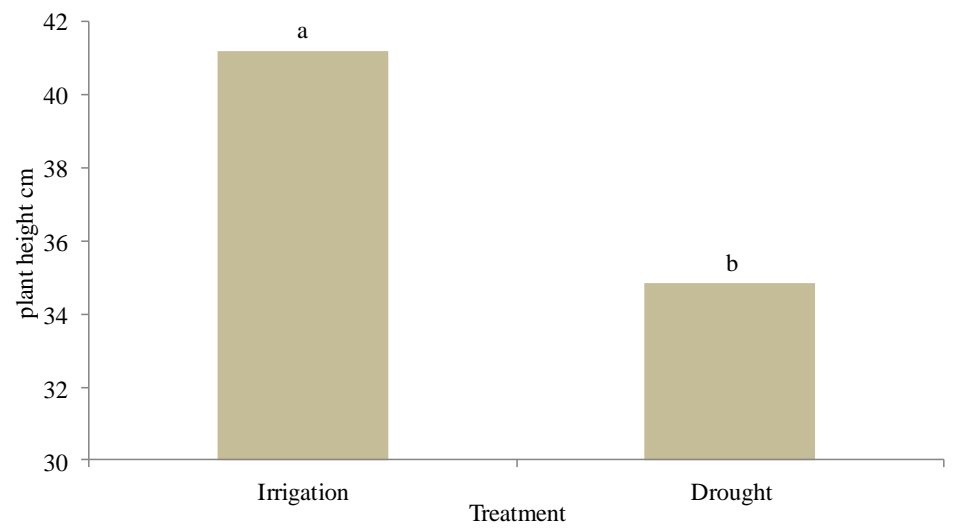

Figure 2. Main effect of treatments on shoot length in tomato

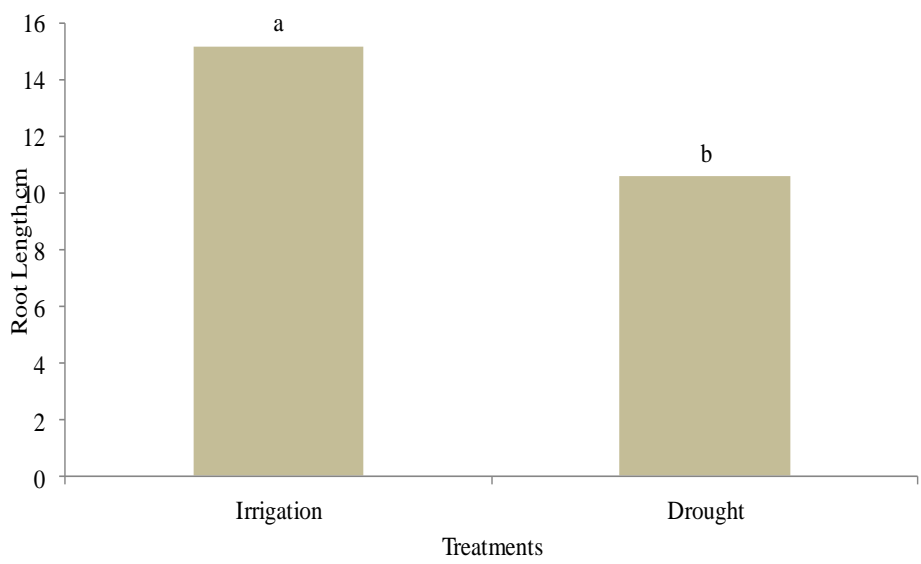

Figure 3. Main effect of treatments on root length of tomato 


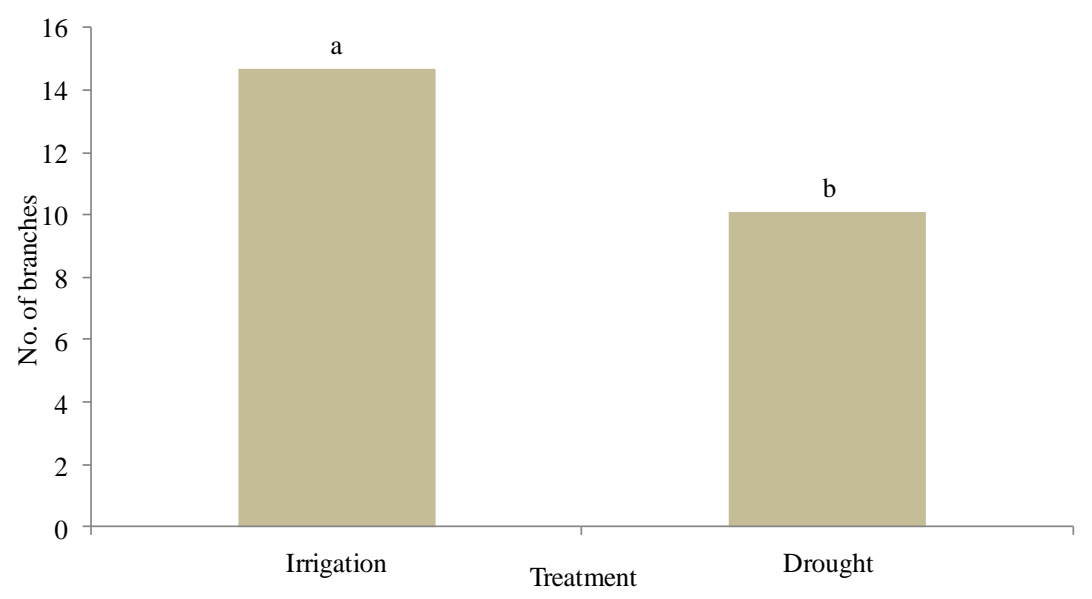

Figure 4. Main effect of treatments on number of branches per plant

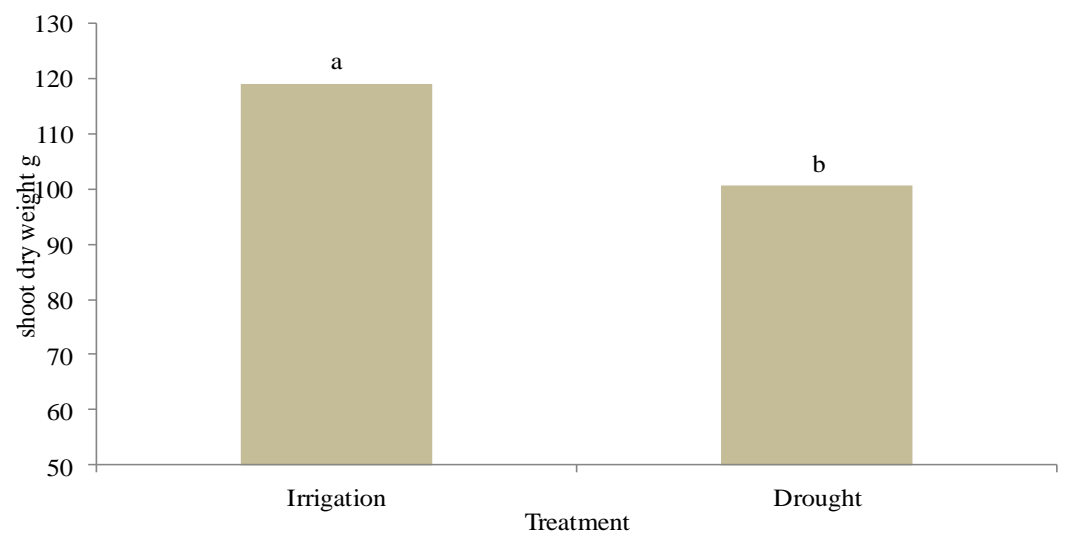

Figure 5. Main effect of treatment on shoot dry weight of tomato

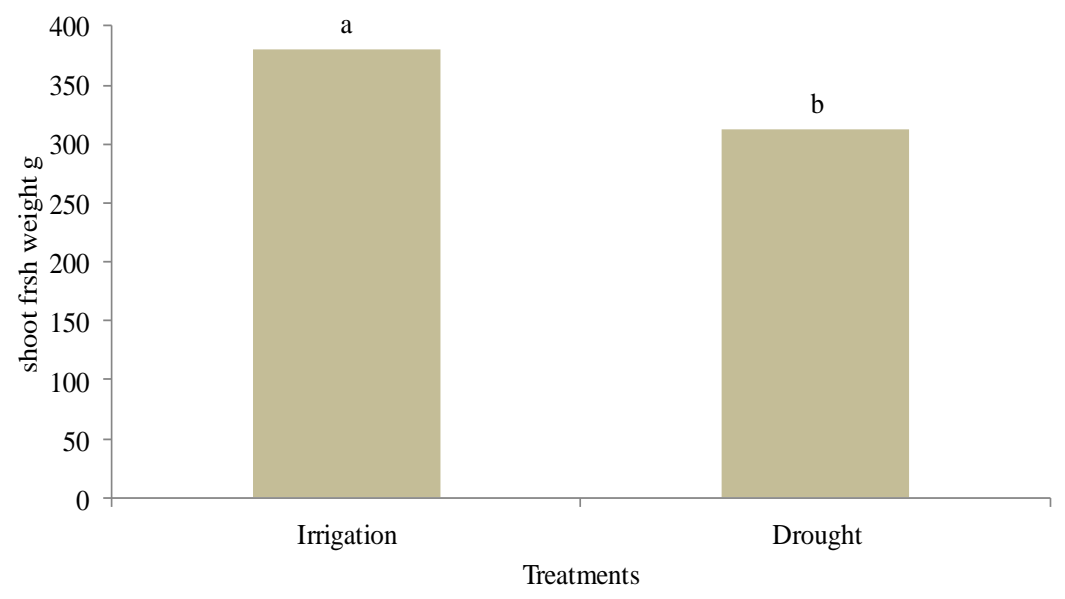

Figure 6. Main effect of treatment on shoot fresh weight of tomato 


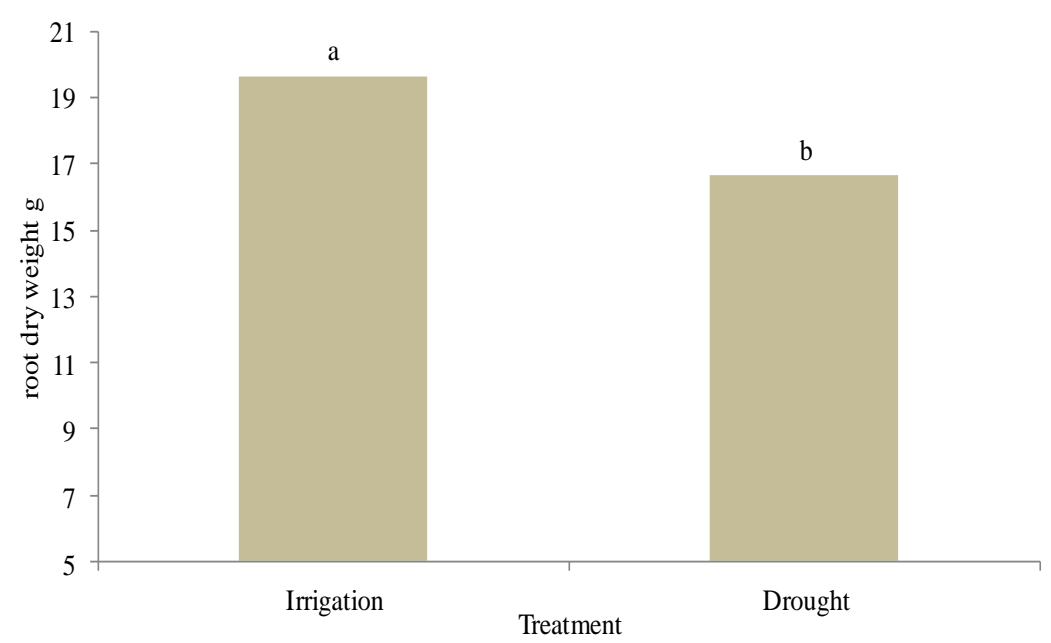

Figure 7. Main effect of treatment on root dry weight

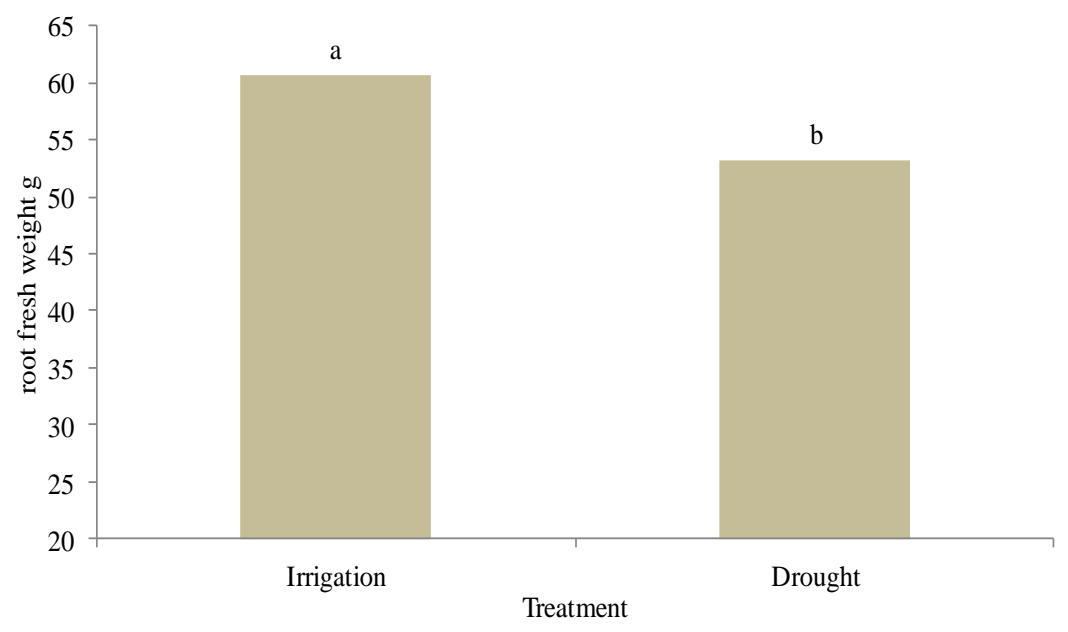

Figure 8. Main effect of treatment on root fresh weight 
Table 3. Genotypic and phenotypic correlation among various plant traits in different tomato genotypes at early growth stage

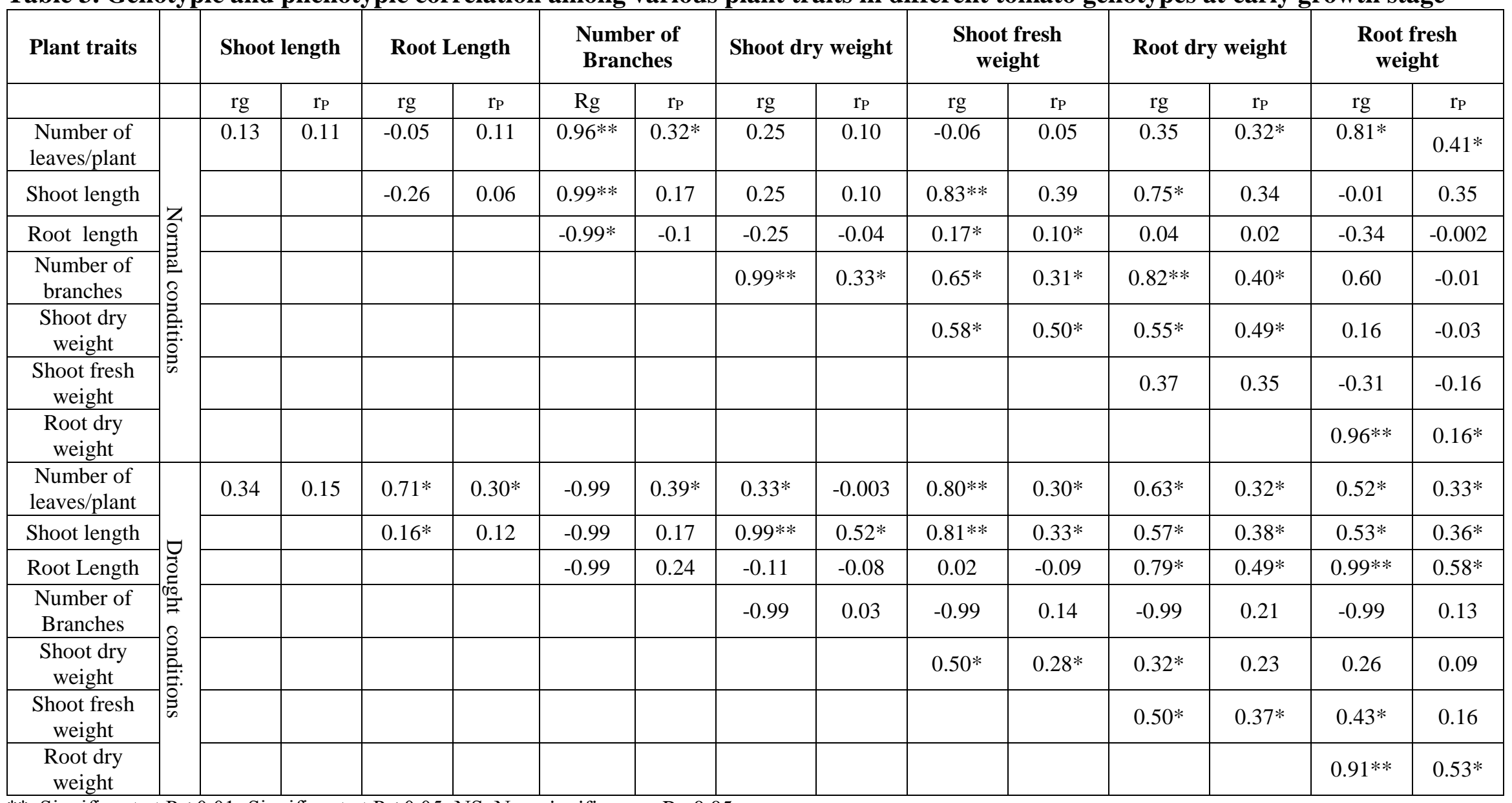

**, Significant at $\mathrm{P} \leq 0.01$; Significant at $\mathrm{P} \leq 0.05 ; \mathrm{NS}$, Non-significant at $\mathrm{P}>0.05$ 


\section{Discussion}

\section{Genetic variability}

Genetic variation was found in all genotypes for both treatments as significant results were found in the study. Similarly interaction between treatments and genotypes were important as they interlink with each other for plant traits. These results were in agreement with some of researchers [14-17] who also found genetic variability in plants due to significant differences in genotypes.

\section{Comparison of means}

Leaf parameters like leaf area and number of leaves are important for photosynthetic activity of plants and contribute to increase fresh biomass. Many varieties of tomato exhibited increased number of leaves and related traits under the study. Similarly, many researchers studied leaf parameters while screening out the genotypes against stress tolerance. They found that in-vitro tolerance of different genotypes of tomato and their assessment for leaf parameters such as density of leaves, thickness of leaves, and stomatal distance at leaves etc. was done to screen out the water stress tolerant genotypes of tomato [18] and most tolerant genotypes were screened out. Water stress strongly affects plant growth and its various attributes including leaves and characteristics of leaves such as chlorophyll content, turgor pressure and senescence of leaves due to higher activity of abscisic acid [19]. As leaves are food factory for plants which if under stress may lead to inhibition of growth as well as impaired protein metabolism and synthesis of amino acids and consequently the less biomass including number of leaves per plant [20]. The number of leaves under water stress condition may be one of promising characteristics of plants in drought defense mechanism. Such a decrease in the number of leaves of Conocarpus erectus was also observed under drought stress conditions [21].
Reason for the reduction in leaves number might be attributed to the changes in cell size and cell division that leads to impaired growth followed by decreased leaf production under drought stress. Most of tomato varieties especially V5 produced maximum number of branches per plant both under normal conditions and drought conditions while variety-7 AVOT-1007 produced minimum number of branches both under normal and drought conditions. Our results are in accordance with the study carried out by Pervez et al. [21] who also reported biomass reduction of tomato by reducing number of branches in response to drought conditions. It was reported that similar findings for chickpea where a greater reduction was seen in vegetative parts with decreased branch production and correspondingly the main shoot became a more dominant component of the total shoot biomass [23]. This reduction in vegetative parameters of plants may be attributed to reduced photosynthetic activity and less water use efficiency of severely affected varieties such as variety 7 . The same argument was proposed by Hsiao and colleagues [24] to support their results.

Among the varieties under water stress conditions, V5 GAISER (60.64) produced maximum root fresh biomass and significant as compared to all other varieties. While V2 SHSHA (52.64) was most severely affected due to water stress and produced minimum root fresh biomass. Our results agree with work of [25] who used PEG to give drought to two tomato varieties and observed that drought stress reduced up ground and below ground fresh biomass. The reason for some varieties to produce high root fresh biomass even under water stress conditions such as V5 may be due to their tolerance to water stress and producing initial roots as a response to stress.

Varieties V5 GASICER (14.25) and V9 DONA (14.24) were persistent in producing 
significantly long roots as relative to rest of varieties both under normal and water stress conditions. [26] found similar result from mutant hybrid produced $8.5 \mathrm{~cm}$ maximum long roots whereas genotype $\mathrm{TG}-5$ had smallest roots $2.2 \mathrm{~cm}$ long. While varieties V2 and V10ROOMA-F1 were the most susceptible to water stress regarding root length parameter. Root characteristics especially root length and root length densities are important for a plant to have comparatively well-established aboveground parts by exploiting the available water. The quantity and quality of plant growth depend on cell division, enlargement and differentiation and all of these events are affected by water stress [27]. This might be the reason for the reduced growth of root length under water stress.

Similarly, V9 DONA (361.87) was producing maximum shoot fresh in both treatments and variety V8 AVOOT-7 (336.08) produced minimum shoot fresh weight. Plant water status strongly influences plant growth and biomass production particularly through its effect on leaf and root extension [18]. Generally, plants response to water stress with a series of physiological mechanisms, which include stomatal closure, repression of cell growth and photosynthesis which may have led to an overall reduction in plant fresh biomass. If any artificial compound such as Glycine Betaine is used to prevent cellular dehydration and maintain turgidity and photosynthetic activity then decrease in the shoot fresh biomass can be overcome in plants growing on low water potential growth.

Varieties V4 and V5 also produced considerable shoot dry biomass while maximum shoot dry weight was found in V9 and V10. Root and shoot characteristics of cotton genotypes were measured by [28] to sort out drought tolerant ones indicating that the varieties that produced more root and shoot dry weight under water stress conditions have genetic potential to tolerate water stress and it was found that these two traits enhance drought tolerance [29]. Some researchers [30] also worked on tomato under normal and water stress conditions and found no significant effect of application of 1/3 (T1) and $2 / 3$ (T2) of full irrigation at seedling stage (as stage-I) on its water uptake efficiency, yield and tomato quality. But water consumption and yield were reduced by application of 1/3 (T3) of irrigation at flowering and fruiting stage (stage-II). Similarly, in order to achieve increased water use efficiency and improved fruit quality of pepper, tomato and water melon an experiment was made in china and scientists found that the specific irrigation water like $25,12,62$ and $15 \mathrm{~mm}$ respectively at seedling stage, vegetative stage and fruit formation and setting stage are important for getting desirable goals of the experiment [31].

\section{Correlation analysis}

A positive and very strong genotypic and phenotypic significant correlation was found between number of leaves per plant and root length. Some researchers found in-vitro tolerance of different genotypes of tomato and evaluated leaf parameters such as density of leaves, thickness of leaves, and stomatal distance in leaves etc. to screen out water stress tolerant genotypes of tomato [17]. Water stress strongly affects plant growth and its various attributes including leaves and characteristics of leaves such as chlorophyll content, turgor pressure of chlorophyll and senescence of leaves due to higher activity of abscisic acid [18]. As leaves are food factory for plants which if under stress may lead to inhibition of growth as well as impaired protein metabolism and synthesis of amino acids and consequently the less biomass including number of leaves per plant [19]. Number of leaves under water stress condition may be one of promising characteristics of plants in drought defense mechanism. Such a decrease in the number of 
leaves of Conocarpus erectus was also observed under drought stress conditions [20]. Number of leaves per plant decreased due to reduction in number of branches in tomato as these traits has negatively correlated with each other. Present results are in accordance with the study carried out by [21] who reported total biomass reduction of tomato branches in response to drought conditions. Similarly, strong genotypic and phenotypic correlation was observed between number of leaves per plant and root fresh weigh was observed. These results are in agreement with work of [24] that used PEG to create drought in two tomato varieties and found drought reduced fresh biomass of root and shoot. Plant water status strongly influences plant growth and biomass production particularly through its effect on leaf and root extension [18]. Generally, plants respond to water stress with a series of physiological mechanisms including stomatal closure, repression of cell growth and photosynthesis which may lead to an overall reduction in plant fresh biomass. If any artificial compound such as glycine betaine is used to prevent cellular dehydration and maintain turgidity and photosynthetic activity then decrease in the shoot fresh biomass can be overcome in plants growing on low water potential growth medium [28]. Fresh shoot length increased shoot fresh weight, fresh root weight and dry root weight. It indicated fresh shoot weight is important for increase of biomass per plant and these results are in favor of research of some scientists [32].

Root length under water stress conditions increased with increased root fresh weight and produced more root fresh weight as deep rooted plants can stand well under drought due to ability to search water deep the soil to overcome shortage of water at soil surface level. Some of the researchers have measured root and shoot characteristics of cotton genotypes to sort out drought tolerant ones indicating that the varieties that produced more root and shoot dry weight under water stress conditions have genetic potential to tolerate water stress and suggested that for drought tolerance [27]. Shoot dry weight was also found to possess strong genetic relationship with root fresh weight. These results were in agreement with some researchers [33] who also worked on tomato when it was grown at optimal and several levels of limited irrigation.

Drought effects on overall growth and development of plant and cause reduction of yield and it was induced by incapability of crop to fulfill its evapotranspiration require and improvement of yield through growth and development of plant on these levels is main objective of the development of water stress tolerant and resistant crop plants [34].

\section{Conclusion}

The present study indicated presence of significant interaction between both normal and water stress conditions has different effect on each variety. Similarly each variety showed different response in both treatments. Vegetative plant traits had positive and significant association with each other. But some traits showed negative and significant relationship like dry shoot weight and root length. Almost all plant traits showed good performance under normal conditions and they also showed stability under water stress conditions. DONA and GIACIER showed best performance for plant traits like root length, fresh shoot weight, fresh root weight, plant height and dry root weight. So, these genotypes are recommended for further breeding programme for development of drought tolerant genotypes.

\section{Authors' contributions}

Conceived and designed the experiments: $S$ Mahpara \& I Andleeb, Performed the experiments: I Andleeb, Analyzed the data: $S$ Mahpara, J Iqbal \& IR Noorka, Contributed materials/ analysis/ tools: IR Noorka \& MA 
Bashir, Wrote the paper: S Mahpara, I Andleeb \& MA Bashir.

\section{References}

1. Heleys L, Lugasi A, Pogonyi A \& Pek Z (2008). Effect of variety and grafting on lycopene contents of tomato (Lycopersicon lycopersicum L. Karsten) fruit. Acta Alimentaria 38(1): 2734.

2. Willcox, K, Catignani GL \& Lazarus S (2003). Tomatoes and cardiovascular health. Critical Reviews in Food Science and Nutrition 43(1): 1-18.

3. Government of Pakistan (2014). Fruit, Vegetables and condiments statistics of Pakistan, 2010-2011. Pakistan Bureau of Statistics, Islamabad, Pakistan 44: 125126.

4. Gulias J, Traveset A, Riera N \& Mus M (2004). Critical stages in the recruitment process of Rhamnus alaternus L. Ann Bot 93: 723-731.

5. Qadir M, Schubert S, Noble AD, Saqib M \& Uallah S (2006). Ameliroration Strategies for salinity induce land degradation. Perspective Agri Vet Sci Nurt Nat Resource 1: 1-12.

6. Shao HB, Chu LY, Jaleel CA, Manivannan P, Panneerselvam R \& Shao MA (2009). Understanding water deficit stressinduced changes in the basic metabolism of higher plants-biotechnologically and sustainably improving agriculture and the ecoenvironment in arid regions of the globe. Crit Rev Biotechnol 29: 131-151.

7. Rezaei MA, Jokar I, Ghorbanli M, Kaviani B \& Masouleh AK (2012). Morphophysiological improving effects of exogenous glycine betaine on tomato (Lycopersicon esculentum Mill.) cv. PS under drought stress conditions. Pl Osmics $J$ 5(2): 79-86.

8. Jurekova Z, Nemelh-Molnar K \& Paganova V (2011). Physiological responses of six tomato (Lycopersicon esculentum Mill.) cultivars to water stress. $J$ of Horticulture and Foresry 3(10): 294300 .
9. Nahar K \& Ullah SM (2011). Effect of Water Stress on Moisture Content Distribution in Soil and Morphological Characters of Two Tomato (Lycopersicon esculentum Mill.) Cultivars. J Sci Res 3(3): 677-682.

10. Foolad MR, Subbiah P, Kramer C, Margrave G \& Lin GY (2003). Genetic relationship among cold, salt and drought tolerance during germination in an interspecific cross of tomato. Euphytica 130: 199-206.

11. Hirayama T \& Shinozaki K (2010). Research on plant abiotic stress responses in the post-genome era: past, present and future. The Plant J 61(6): 1041-1052.

12. Steel RGD, Torrie JH \& Discky DA (1997). Principles and procedures of statistics: A Biometrical Approach, $3^{\text {rd }}$ ed. McGraw Hill Book Co., New York.

13. Kwon SH \& Torrie JH (1964). Heritability and inter-relationship among traits of two Soybean Populations. J Crop Sci 4: 196198.

14. George S, Jatoi SA \& Siddiqui SU (2013). Genotypic differences against PEG simulated drought stress in Tomato. PakJ Bot 45(5): 1551-1556.

15. Shamim F, Farooq K \& Waheed A (2014). Effect of different water regimes on biometric traits of some tolerant and sensitive tomato genotypes. Journal of Animal \& Plant Sci 24(4): 1178-1182.

16. Andleeb I (2016). Effect of Water stress for various plant traits in tomato at vegetative stage. M.Sc. (Hons.) Thesis, Department of Pant Breeding \& Genetics, Ghazi University, D. G. Khan, Pakistan.

17. Jokanovic MB, Girek Z, Pavlovic S, Ugrinovic M \& Zdravkovic J (2017). Traits Related to Drought Tolerance in Tomato Accessions of Different Growth Type and Fruit Size. The J of Animal \& Plant Sci 27(3): 869-876.

18. Manoj K \& Deshpande U (2007). In Vitro screening of tomato genotypes for drought resistance using polyethylene glycol. African J of Biotechnol 6: 691-696. 
19. Beadle CL, Ludlow MM, Honeysett JL (1993) Water relations. In: HALL D O (Ed.) Photosynthesis and Production in a changing environment - a field and laboratory manual. Chapman \& Hall. London, UK.

20. Larcher W (2003). Physiological Plant Ecology. Ecophysiology and stress physiology of functional groups. $4^{\text {th }} \mathrm{Ed}$., Berlin: Springer.

21. El-Juhany LIA \& Ibrahim M (2005). Interactive effects of low water supply and high salt concentration on the growth and dry matter partitioning of Conocarpus erectus seedlings. Saudi J Biol Sci 12: 147157

22. Pervez MA, Ayube CM, Khan HA, Shahid MA \& Ashraf I (2009). Effect of drought stress growth and yield seed quality of tomato (Lycopersicon esculentium L.). Pak J Agric Sci 46(3): 174-178.

23. Ibrahim AK (1990). Studies on growth and yield of Chickpea. A Ph.D. Thesis, Univ. of Wales, Bangor, UK.

24. Hsiao TC, Silk WK \& Jing J (1985). Leaf growth and water deficits: Biophysical effects. In: Control of leaf growth. Baker NR, Davies WJ, Ong CK (eds) Cambridge Univ. Press, Cambridge. pp 239-266.

25. Ayaz M, Ahmad R, Shahzad M, Khan NU, Shah MM \& Khan SA (2015.) Drought stress stunt tomato plant growth and upregulate expression of SIAREB, SINCED and SIERF024 genes. Scientia Horticulturae 195: 48-55.

26. Kulkarni M \& Deshpande U (2007). In Vitro screening of tomato genotypes for drought resistance using polyethylene glycol. African J Biotechnol 6(6): 69-96.

27. Kusaka M, Ohta M \& Fujimura T (2005). Contribution of inorganic components to osmotic adjustment and leaf folding for drought tolerance in pearl millet. Physiol Plant 125: 474-489.

28. Basal H, Bebeli P, Smith CW \& Thaxton $P$ (2003). Root growth parameters of converted race stocks of upland cotton and two $\mathrm{BC}_{2} \mathrm{~F}_{2}$ populations. Crop Sci 43: 1983-1988.

29. Agboma PC, Sinclair TR, Jokinen K, Peltonen-Sainio P \& Pehu E (1997). An evaluation of the effect of exogenous glycine betaine on the growth and yield of soybean: timing of application, watering regimes and cultivars. Field Crop Res 54: 51-64.

30. Chen J, Kang S, Du T, Qui R, Guo P \& Chen R (2013). Quantitative response of greenhouse tomato yield and quality to water deficit at different growth stages. Agri Water Management 129:152-162.

31. Yang H, Du T, Qiu R, Chen J, Wang F, Li Y, Wang C, Gao L \& Kang S (2017). Improved water use efficiency and fruit quality of greenhouse crops under regulated deficit irrigation in northwest China. Agric Water Management 179: 193-204.

32. Jafri SJ, Ali SS, Mahmmod A \& Butt MA (1991). Genetic parameter for seedling vigor of some rice genotype (Oryza sativa L.) genotypes. The JAPS 1: 233-265.

33. Wahb-Allah MA, Alsadon AA \& Ibrahim AA (2011). Drought tolerance of several tomato genotypes under greenhouse conditions. World Applied Sciences Journal 15: 933-940.

34. Blum A (2018). Plant Breeding for Stress Environments. CRC Press Taylor \& Francis Group, New York, USA. 